\title{
ANALISIS PERKEMBANGAN SOSIAL EMOSIONAL TIDAK TERCAPAI PADA SISWA KELAS 1 DI SD JARANAN, BANGUNTAPAN, BANTUL YOGYAKARTA
}

\author{
M. A Dhalu1, Aprinaldo Anrada ${ }^{2}$ \\ Pascasarjana \\ Pedididikan Guru Madrasah Ibtidaiyah, Fakultas Ilmu Tarbiyah Dan Keguruan, Uin \\ Sunan Kalijaga, Yogyakarta, Indonesia \\ milantiedhalu@gmail.com
}

\begin{abstract}
Abstrak
Penelitian ini bertujuan untuk mengetahui tidak tercapainya perkembangan sosial anak dan untuk mengetahui tidak tercapainya perkembangan emosional anak. Penelitian ini menggunakan metode analisis kualtitatif. Subjek dari penelitian ini adalah siswa kelas 1 SDN Jaranan dengan jumlah 20 orang. Data penelitian ini dikumpulkan melalui wawancara. Penelitian ini dilaksanakan 1 kali. Hasil dari penelitian ini menunjukkan bahwa ada beberapa siswa kelas 1 SDN Jaranan mengalami keadaan baik sosial maupun emosional yang bermasalah seperti mengacu kepada indikator wawancara peneliti tentang penyesuain diri dalam bersosial, kurang nya berinteraksi dengan teman sebaya, keadaan siswa ketika ia dimarahi oleh guru, menyebabkan berperilaku sensitif dilingkungan sekolah. Keadaan ini peneliti temukan ketika dilapangan. Dari semua hal ini peneliti dapat memberikan analisis bahwa mengatasi anak yang keadaan sosial emosional nya tidak baik, bisa dilakukan dengan memberikan stimulus, perhatian maupun pendekatan secara langsung kepada anak yang mengalami hal tersebut. Maka dari hal itu mengatasi ketidak tercapain dari sosial emosional anak bisa dilakukan bersama-sama baik oleh guru dan orang tua sehingga anak bisa memiliki keterampilan sosial emosional yang baik dalam bersosial dilingkungannya.
\end{abstract}

Kata kunci: sosial, emosional, penyesuain diri, interaksi.

\section{PENDAHULUAN}

Anak merupakan invetasi bagi orangtua dimasa depan. Semua orang tua menginginkan anaknya sukses. Oleh karena itu berbagai upaya dilakukan orang tua untuk mewujudkannya. Dalam diri setiap anak perlu dikembangkan nilai-nilai dasar yang dapat digunakan secara fungsional dalam kehidupannya. Diantara aspek mendasar adalah pengembangan sosial emosional yang memadai. Sejak dini anak harus sudah dikenalkan pada kemampuan mengenali, mengolah, dan mengontrol emosi, serta perilaku sosialnya agar dapat merespon dengan baik setiap kondisi emosi dan sosial yang muncul dihadapannya (Ali Nugraha dan Yeni Rachmawati, 2006:5)

Perkembangan sosial emosional anak adalah kepekaan anak untuk 
memahami perasaan orang lain ketika berinteraksi dalam kehidupan seharihari. Tingkat interaksi anak dengan orang lain dimulai dari orang tua, saudara, teman bermain hingga masyarakat luas. Dapat diketahui bahwa perkembangan sosial emosional tidak dapat dipisahkan satu sama lain. Dengan kata lain membahas perkembangan emosi harus bersinggungan dengan perkembangan sosial, begitu pula sebaliknya karena keduanya terintegrasi (Suyadi, 2010:109).

Perkembangan sosial emosional harus dikenalkan sejak dini, ketika anak tidak diajarkan maka hal yang terjadi adalah kurangnya memiliki keterampilan dalam mengolah emosi dan sosial yang mana akan mempengaruhi kehidupan dalam bermasyarakat, maka dari itu keterampilan dalam mengatur emosi dan sosial harus diajarkan kepada anak sejak usia dini.

Berkenaan dengan perkembangan sosial emosional anak tidak tercapai bila mana anak ketika melakukan interaksi baik bersama teman sebaya, orang tua dan guru, ia kurang memiliki rasa bersosialisasi dengan orang lain. Seperti penulis temukan dilapangan bahwasannya, ketika kondisi dalam pembelajaran kelas maupun dalam lingkungan sekolah ada banyak anak yang kurang untuk bergaul karena belum bisa untuk menyesuaikan diri dalam menjalin interaksi dengan orang lain ketika bersosial.

Studi Kasus tentang kurang nya sosial, maraknya kasus kekerasan pada anak akhir-akhir ini disebabkan karena menurunnya rasa sosial diantara warga. Masyarakat, khususnya di kota-kota besar cenderung cuek dan enggang bersosialisasi. Karena rasa antisosial itulah, maka kekerasan pada anak kerap terjadi. Faktanya kekerasan terhadap anak itu muncul dilingkungan domestik, misalnya ketika seorang tetangga tahu ada orang tua yang melakukan kekerasan pada anak namun cuek dia tidak menghiraukannya. Oleh karena itu perlindungan anak Indonesia mengimbau agar sosialisasi antar tetangga harus dikembalikan ditengah pesatnya iklim modernisasi yang diidentik dengan individualisme (Detik News.com, 2013)

$\begin{array}{ccc}\text { Setiap } & \text { anak } & \text { harus } \\ \text { mengekpresikan } & \text { dirinya } & \text { dalam }\end{array}$
berinteraksi dengan orang lain. Seperti penulis temukan dilapangan bahwasannya ada beberapa anak merasa kespian dan murung sendiri tidak senang seperti teman lainnya, hal ini disebabkan karena keadaan emosional nya terganggu kemudian ada lain lebih mudah cemas serta kurang bisa mengendalikan dirinya sendiri dalam bergaul baik dengan 
teman maupun guru. maka hal ini menjadi problem yang harus diselesaikan, sehingga anak bisa memiliki keterampilan dalam mengatur keadaan emosinal dan sosialnya. Adapun tujuan dari penelitian ini, yaitu untuk mengetahui penyebab tidak tercapainya perkembangan sosial anak dan untuk mengetahui penyebab tidak tercapainya perkembangan emosional anak?

\section{KAJIAN PUSTAKA}

Kajian pustaka adalah kegiatan mendalami, mencermati, menelaah dan mengindentifikasi pengetahuan, atau hal-hal yang telah ada untuk mengetahui apa yang ada dan yang belum ada (Suharsimi Arikunto, 2000:75).

Adapun refrensi yang memiliki kedekatan topik dengan penelitianini antara lain:

$$
\text { Dalam buku Metode }
$$

Pengembangan Sosial Emosional karya Ali Nugraha dan Yeni Rahmawati (2006). Buku ini membahas tentang dasar teoritis tentang perkembangan emosi sosial pada individu, mekanisme terjadinya berbagai emosi dalam diri manusia, dan penahaan perkembangan sosial.

Buku Psikologi Pendidikan dalam Perspektif Baru karya Purwa Atmaja Prawira (2013) membahas tentang perilaku manusia dalam upaya pengajaran dan pembelajaran di lingkungan sekolah, disebutkan bahwa sangat pentingnya mengajarkan tentang penanaman emosional kepada anak. Karena banyak yang bisa ditemukan bahwasannya anak yang dikategorikan cerdas di sekolah, tetapi ia mudah marah, mudah putus asa atau bersikap angkuh dan sombong. Hal ini disebabkan ketidakmampuan si anak dalam mengelola emosinya (Purwa Atmaja Prawira, 2013:162)

Buku Observasi Perkembangan Anak Usia Dini karya Jenis J. Beaty membahas tentang mengembangkan emosi pada anak-anak kecil, dikatakan bahwasannya respons emosional pada anak yang terjadi adalah seperti merasa kekhwatiran, merasa kesedihan, merasa keterkejutan, adanya kasih sayang dan rasa senang yang semua kategori ini merangkup menuju perkembangan emosional (Jenis J. Beaty, 2013:93).

\section{METODE PENELITIAN}

Subjek dalam penelitian ini adalah sebanyak 20 orang yang terdiri dari 10 siswa laki-laki dan 10 siswi perempuan. Jumlah sampel penelitian ini adalah 20 orang. Data sampel ini adalah kelas 1 SDN Jaranan.

Variabel-variabel yang ada dalam penelitian ini adalah variabel (X) yaitu tidak tercapainya perkembangan sosial anak, sedangkan 
variabel (Y) yaitu tidak tercapainya perkembangan emosional anak.

Perkembaangan sosial adalah suatu proses kemampuan belajar dari tingkah laku yang ditiru dari keluarganya serta mengikuti. Perkembangan sosial sendiri adalah perilaku anak dalam menyesuaikan diri ketika ia bersosial. Tidak tercapainya anak dalam bersosial adalah disebabkan belum ada rasa memiliki untuk bersosialisasi dengan orang lain. Sosialisasi adalah suatu proses dimana indivisu terutama anak dapat melatih kepekaan dirinya terhadap sosial terutama belajar dalam bergaul dengan bertingkah laku, sepertt orang lain didalam lingkungan sosialnya (Winda Gurnati, 2010:53).

\section{Perkembangan}

emosional adalah suatu keadaan pada diri individu pada suatu waktu tertentu yang diwarnai dengan adanya rasa keemosionalan seperti rasa sedih, gembira dan cinta. Tidak tercapainya perkembangan emosional anak adalah bahwasanya ketika ia berinteraksi dengna ornag lain, anak tidak bisa mengkoondisikan perasaannya sehingga ia mudah untuk menjadi kadang sedih berubah jadi gebira ataupun benci yang dapat mempengaruhi bagaimana anak berfikiri dan bertindak mengenai perasaan tersebut (Yudrik Jahja, 2012:136).
Teknik analisis data yang digunakan untuk mengetahui tidak tercapainya sosial dan emosional adalah teknik analisis data kualitatif. Instrumen pengumpulan data menggunakan observasi, wawancara, dan dokumentasi.

HASIL PENELITIAN DAN ANALISIS

\section{Hasil Penelitian}

Hasil penelitian disini menggunakan instrumen wawancara yang sampel nya adalah guru dan siswa kelas 1 SDN Jaranan. Berkenaan dengan hal ini peneliti akan memberikan bahan wawancara serta indikator yang digunakan untuk menunjang pertanyaan-pertanyaan yang diberikan kepada guru dan siswa kelas 1 SDN jaranan dengan jumlah 20 orang siswa.

a. Indikator Perkembangan Sosial Tidak Tercapai. Indikator sosial terdiri dari: 1) Tingkah laku; 2) Bergaul (bersosialisasi); Menyesuaikan diri; 4) Kepribadian; dan 5) Jalinan interaksi.

b. Indikator Perkembangan Emosional Tidak Tercapai. Indikator emosional terdiri dari: 1) Berlaku sensitif; 2) Keadaan psikologis; 3) Rasa takut; 4) Kondisi perasaan; 5) Kondisi kejiwaan. 
Tabel 1.1 Instrumen wawancara dengan guru kelas 1 SDN Jaranan

\begin{tabular}{|c|c|c|}
\hline No & Pertanyaan & Tanggapan \\
\hline 1 & $\begin{array}{l}\text { Bagaimana cara guru mengatasi tingkah } \\
\text { laku anak yang bermasalah? }\end{array}$ & $\begin{array}{l}\text { Secara keseluruhannya siswa diberi } \\
\text { pendekatan secara khusus, anak mempunyai } \\
\text { kelakuan baik dengan temannya bisa juga } \\
\text { memberi tau kepada kedua orang tuanya } \\
\text { tentang masalah yang dilakukan oleh anaknya } \\
\text { di sekolah, sehingga guru orang tua bisa } \\
\text { singkron. }\end{array}$ \\
\hline 2 & $\begin{array}{l}\text { Apa penyebab anak didik kurang untuk } \\
\text { bergaul sesama teman sebayanya? }\end{array}$ & $\begin{array}{l}\text { Harus melibatkan semua sekolah untuk } \\
\text { mengahadapi problem, sebaiknya guru } \\
\text { memberi motivasi, tinggal kita bisa mengcover } \\
\text { semua teman teman itu sehingga anak itu } \\
\text { tidak rendah diri dan minder, semua harus } \\
\text { dilibatkan termasuk kepala sekolah, kelas anak } \\
1 \text { suka minder bisa diberikan kerjaan coba } \\
\text { berikan buku ini sama kepada kepala sekolah } \\
\text { itu bisa mengatasi minder, anak kelas } 1 \text { ini } \\
\text { juga susah diatur rame selalu. }\end{array}$ \\
\hline 3 & $\begin{array}{l}\text { Bagaimana guru mengatasi siswa dalam } \\
\text { menyesuaikan diri ketika bersosial }\end{array}$ & $\begin{array}{l}\text { Orang tua nya dipanggil, diadakan kerja sama } \\
\text { untuk menanyakan dan membantu supaya } \\
\text { anak mau berteman }\end{array}$ \\
\hline 4 & $\begin{array}{l}\text { Mengapa terjadi siswa sulit untuk } \\
\text { menjalin interaksi dengan gurunya? }\end{array}$ & $\begin{array}{l}\text { Karena kurang kedekatan dengan guru, } \\
\text { hubungan sama orang tuanya kurang baik, na } \\
\text { saya baru mengajar dikelas } 1 \text { ini, baru } 4 \text { bulan } \\
\text { tapi kalau dikelas } 6 \text { sudah } 14 \text { tahun }\end{array}$ \\
\hline 5 & $\begin{array}{l}\text { Bagaimana cara guru mengatasi anak } \\
\text { yang kepribadian sosialnya kurang baik? }\end{array}$ & $\begin{array}{l}\text { Guru harus mempunyai ilmu psikologi anak, } \\
\text { guru harus rajin mendekati dalam } \\
\text { perkembangan anak }\end{array}$ \\
\hline 6 & $\begin{array}{l}\text { Apa penyebab anak menjadi berlaku } \\
\text { sensitif? }\end{array}$ & $\begin{array}{l}\text { Guru harus mempunyai emosional anak, } \\
\text { harus punya ilmu psikologi anak, guru harus } \\
\text { rajin memonitor siswa, penerimaan raport } \\
\text { diajak orang tuanya }\end{array}$ \\
\hline 7 & $\begin{array}{l}\text { Bagaimana keadaan psikologis anak } \\
\text { ketika ia dimarahi? }\end{array}$ & $\begin{array}{l}\text { Takut anak itu pasti takut, seperti } \\
\text { memecahkan kaca tidak usah ditegur itu } \\
\text { sudah tidak berani sendiri, ini guru harus } \\
\text { mendekati siswa, supaya tidak takut anak } \\
\text { harus diberi motivasi, dipuji apa masalah nya } \\
\text { terus bagaimana guru mengatasi rasa takut } \\
\text { siswa itu tadi. Anak-anak biasanya kalau } \\
\text { dipanggila orang tua nya sudah takut, kami } \\
\text { disini bisa melalui WA karena di kelas ini } \\
\text { sudah memiliki grup WA dengan orang tua } \\
\text { nya dikelas satu ini }\end{array}$ \\
\hline
\end{tabular}




\begin{tabular}{|l|l|l|}
\hline 8 & $\begin{array}{l}\text { Apa yang menyebabkan problem } \\
\text { terjadinya rasa takut pada anak? }\end{array}$ & $\begin{array}{l}\text { Karena orang tua, kadang-kadang didikanya } \\
\text { keras, siswa disini bermacam latar belakang } \\
\text { ada ditinggal ibunya ada juga tinggal dengan } \\
\text { neneknya, ada juga ditinggal ayah nya }\end{array}$ \\
\hline 9 & $\begin{array}{l}\text { Adakah pengaruh perilaku guru terhadap } \\
\text { kondisi perasaan siswa? }\end{array}$ & $\begin{array}{l}\text { Ada ketika guru memberikan nasehat ketika } \\
\text { anak melakukan kesalahan, anak akan takut, } \\
\text { guru harus memotivasi siswa sehingga anak } \\
\text { bisa senang lagi }\end{array}$ \\
\hline 10 & $\begin{array}{l}\text { Bagaimana keadaan kejiwaan anak ketika } \\
\text { ada masalah emosional dengan teman } \\
\text { sebaya maupun guru yang ada di } \\
\text { lingkungan sekolah? }\end{array}$ & $\begin{array}{l}\text { Anak kelas 1 itu suka minder, anak itu disuruh } \\
\text { tenang tidak bisa, kalau anak rame itu positif } \\
\text { berarti ada timbal balik, ada anak yang suka } \\
\text { diam karena takut untuk berteman nah guru } \\
\text { harus mendekati anak itu }\end{array}$ \\
\hline
\end{tabular}

\section{Analisis Hasil Penelitian}

Berdasarkan hasil analisis dari observasi wawancara yang peneliti lakukan di kelas 1 SDN Jaranan bahwasannya dilihat dari bahasaan mengani tingkah laku anak yang bermasalah, maka guru mengatasi dengan secara keseluruhan nya siswa diberi pendekatan secara khusus, anak mempunyai kelakuan baik dengan temannya bisa juga memberi tau kepada kedua orang tuanya tentang masalah yang dilakukan oleh anaknya disekolah, sehingga guru orang tua bisa singkron. Di sini dapat diketahui bahwa salah satu mengatasi problem anak yang mengalami masalah sosioal nya adalah memberikan pendekatan khusus dan juga ada pembicaraan dengan orang tua anak secara bertahap guna mengatasi sosial anak sehingga ia bisa bersosialisasi lagi baik dengan temannya maupun dengan gurunya.
Ketika peneliti berada dilapangan, peneliti menemukan anak kurang untuk bergaul bersama teman sebayanya, maka dari ini peneliti juga bertanya dengan guru apa yang menyebabkan hal itu, dari jawaban guru harus melibatkan semua sekolah untuk mengahadapi problem, sebaiknya guru memberi motivasi, tinggal kita bisa mengcover semua teman teman itu sehingga anak itu tidak rendah diri dan minder, semua harus dilibatkan termasuk kepala sekolah, kelas anak 1 suka minder bisa diberikan kerjaan coba berikan buku ini sama kepada kepala sekolah itu bisa mengatasi minder, anak kelas 1 ini juga susah diatur rame selalu.

Kemudian peneliti juga berbicara dengan guru berkenaan dengan penyesuaian diri anak dalam bersosial, seperti yang ditanggapi guru adalah Orang tua nya dipanggil, diadakan kerja sama untuk menanyakan dan membantu supaya 
anak mau berteman. Dari hal ini dapat dilihat dikala anak didik bermasalah di lingkungan sekolah maka ada antisipasi yang dilakukan oleh guru dengan melakukan kontak langsung dengan orang tua anak yang bersangkutan untuk menjalin kerja sama mengatasi anak bisa untuk bersosial.

Terlepas dari hal itu peneliti juga masuk kepada bahasan mengenai pengatasan masalah anak dalam berinteraksi, bagaimana cara seorang guru untuk mengatasi hal itu, dari jawaban guru dapat dilihat bahwa Karena kurang kedekatan dengan guru, hubungan sama orang tuanya kurang baik. Dari hal ini dapat dilihat bahwa ada suatu problem yang dihadapi anak bukan hanya masalah di lingkungan sekolah namun juga dirasakan anak dilingkungan keluarga.

Dalam perkembangan sosial dukungan keluarga juga berperan untuk pemberian rasa nyaman baik secara fisik maupun psikologis yang dapat berupa perhatian, informasi, saran dan nasihat baik berbentuk verbal atau nonverbal, rasa dihargai dan disayangi yang diberikan oleh orang tua, kerabat, atau anggota keluarga lainnya (Umi Kulsum, Sri Wirurachmi, Binti Muchrini Jurnal, 2017:27)

Berkenaan dengan emosional, peneliti juga ikut membahas manakalah ada anak didik yang mengalami dalam pergaulannya dengan perilaku yang notabenenya mudah untuk sensitif, apa yang menyebabkan hal ini, dari jawaban guru dapat dikatakan bahwa ada pola ajaran perilaku dari orang tua yang kurang baik didalam rumah seperti ada pertengkaran atau hal lainnya, ada juga sering dimarahi maka hal ini akan berdampak pada psikologis anak dan menyebabkan ia bisa jadi berperilaku menjadi tidak baik.

Kedekatan seorang ibu dengan anaknya dapat mendukung kualitas adapatasi sosial dalam kelompok teman sebaya. Kedekatan ibu-anak menyediakan pondasi yang positif dan menjadi faktor berpengaruh terhadap perkembangan sosialiasi pada anak. Anak yang merasa yakin menerima lingkungannya akan mengembangkan rasa percaya diri untuk berteman dengan teman sebayanya (Ani Wijrahayu, Diah Krisnatul, Istiqlahiyah Jurnal, 2018:173)

Dalam mengatasi ketidak tercapaian dari sosial emosional anak maka peran guru dan orang tua harus ikut andil dalam mengatasi problem masalah yang dihadapi oleh anak. Banyak hal yang bisa dilakukan seperti melakukan pendekatan secara langsung, bisa juga memberikan perhatian lebih, maupun dengan melakukan konteks pembicaraan langsung dengan anak apalagi kepada 
anak yang mengalami keadaan sosial nya kurang baik ataupun anak yang mengalami keadaan emosional nya kurang baik maka kita selaku guru maupun orang tua bisa memberikan stimulus motivasi atau hal lainnya sehingga bisa teratasi permasalahan ini.

\section{PEMBAHASAN}

\section{Teori Perkembangan}

Berangkat dari rumusan masalah penelitian bahwasanya penyebab tidak tercapainya perkembangan sosial emosional maka dari itu peneliti akan mengkaji hal ini. Berkenaan dengan perkembangan sosial emosional ini berhubungan dengan kehidupan anak yang berada di lingkungan sekolah, berinterkasi dengan teman sebaya, bergaul dengan guru, maupun berteman dengan orang tua. Anak memiliki bermacam-macam kondisi mengatur keadaan emosional nya dalam berteman. Maka dari itu perlu pendekatan dari berbagai pihak sekolah maupun orang tua.

Perkembangan merupakan terjemahan dari developmental. Perkembangan berorientasi pada psikologis/kejiwaan atau mental. Perkebangan berkaitan dengan perubahan kualittaif dan kuantitatif. Dapat di definisikan sebagai deretan progresif bahwa perubahannya terarah, mebimbing mereka maju dan bukan mundur. "Teratur" dan
“Koheren" menunjukkan adanya hubungan nyata antara perubahan yang terjadi da yang telah terjadi atau yang akan terjadi.

Berkenaan dengan teori perkembangan sendiri peneliti membagi dalam tiga teori yang terdiri dari teori perkembangan nativisme, teori perkembangan emprisme, dan teori perkembangan konvergensi.

a. Nativisme. Tokoh aliran ini adalah Schoupenhour Perkembangan dipengaruhi oleh faktor bawaan atau keturunan. Paham ini akan mempengaruhi sikappendidikan dan peran pendidikan bahwa menurut teori ini, pendidikan tidak berperan. Hal ini membuat adanya sikap negatif terhadap pendidikan.

b. Empirisme. Tokoh aliran ini adalah John Locke. Menurut aliran ini perkembangan dipengaruhi oleh lingkungan. Aliran ini menyebabkan adanya sikap yang over optimis terhadap pendidikan, padahal tidak semua pengalaman dari lingkungan yang menyebabkan individu bebeda.

c. Konvergensi. Tokoh aliran ini adalah William Stern. Perkembangan dipengaruhi oleh pembawaan dan lingkungan. Aliran ini mengatakan pada perkambangan bahwa lingkungan termasuk pendidikan berpengaruh pada perkembangan dan pertmbuhan, begitu pula dengan 
faktor genetik (Rifa Hidayah, 2009:3)

Psikologi perkembangan adalah studi psikologi yang mempelajari perkembangan manusia dan faktorfaktor yang membentuk perilaku seseorang sejak lahir sampai lanjut usia. Psikologi perkembangan berkaitan erat dengan psikolgi sosal, karena sebgian besar perkembangan terjadi dalam konteks adanya interaks sosial. Psikologi perkembangan adalah cabang dari ilmu psikologi yang mempelajari perkembangan dan perubahan aspek kejiwaan manusia sejak dilahirkan samapi dengan mati.

Psikologi sosial bidang ini mempunyai tiga ruang lingkup, antara lain:

a. Studi tentang pengaruh sosial terhadap proses individu, misalnya: studi tentang persepsi, motivasi proses belajar, atribusi (sifat)

b. Studi tentang proses-proses individual bersama, seperti bahasa, sikap sosial, dan perilaku meniru.

c. Studi tentang interaksi dengan kelompok, misalnya, kepemimpinan, komunikasi hubungan kekuasaan, kerjasama dalam kelompok, persaingan, konflik (Yuridik Jahja, 2011:23)

\section{Perkembangan Sosial}

Pada proses integrasi dan interaks ini faktor intelektual dan emosional mengambil peranan penting. Proses ini merupakan proses sosialisasi, yang mendudukan anakanak sebagai insan yang secara aktif melakukan proses sosialisasi. Perkenalan dan pergaulan dengan manusia lain segera menjadi luas: ia mengenalkan kedua orangtuanya, anggota keluarganya, teman bermain sebaya, dan teman-teman sekolahnya. Pada umur selanjutnya, sejak anak mulai belajar sekolah, mereka mulai belajar mengembangkan interaksi sosial dengan belajar menerima pandangan kelompok (masyarakat), memahami tanggung jawab, dan berbagai pengertian dengan orang lain.

Perkembangan sosial emosional anak perlu dikembankan sejak dini karena banyak hal yang akan dilakukan anak dengan orang lain. Kegiatan sehari-hari anak juga memerlukan keterampilan sosial emosional untuk menunjang keberhasilan kegiatan anak misalnya dalam bermain dengan teman sebaya atau lingkungan sekitar. Perkembangan sosial anak akan berkembang dengan seiring waktu bertambah umurnya anak (Nur Shintiya, Ni Made Sulastri, Luh Ayu Tirtayani, 2015:e-Journal PG PAUD)

Berdasarkan perkembangan sosial, kebutuhan sosial anak makin kompleks, dan hubungan sosialnya makn luas, anak perlu memahami orang dewasa selain orang tua 
termasuk guru, anak sudah memerlukan teman sebaya, terlihat pada usa 2 dan 3 tahun anak menunjukkan minat yang nyata terhadap anak-anak lain, karena perlu di upayakan terealisasinya pendidikan anak usa dini.

\section{Perkembangan Emosi}

Pada masa perkembangan anak dan remaja tentunya akan melewati dalam pengaruh emosional. Emosi sendiri dapat dikatakan bahwa suatu keadaan perasaan yang kompleks disertai dengan kegiatan kelenjar dan motoris. Emosional sendiri terdapat pada setiap keadaan pada diri seseorang yang disertai warna efektif baik pada tingkat lemah maupun dalam tingakat yang luas.

Emosional juga berfengaruh pada perilaku dan perubahan fisik seseorang maka dari itu peneliti menuliskan dibawah ini ada beberapa contoh tentang pengaruh emosi sendiri terhadap perilaku individu seseorang diantaranya:

a. Memperkuat semangat, apabila orang merasa senang atau puas atas hasil yang dicapai.

b. Melemahkan semangat, apabila timbul rasa kecewa karena kegagalan dan sebagai puncak dari keadaan ini ialah timbulnya rasa putus asa (frustasi).

c. Menghambat konsentrasi belajar, apabila sedang mengalami ketegangan emosi dan dapat juga menimbulkan sikap gugup dan gagap dalam berbicara.

d. Terganggunya penyesuaian sosial, apabila terjadi rasa cemburu dan iri hati.

e. Suasana emosional yang diterima dan dialami individu semasa kecilnya akan mempengaruhi sikapnya di keudian hari, baik terhadap dirinya maupun orang lain.

Di usia sekolah, anak belajar tentang berbagai macam bentuk emosi dan bagaimana mengekspreskannya dari apa yang ia lihat dan pelajari dari orang tua, guru, maupun teman sebayanya. Menurut Elisenberg et al (dalam Rifa Hidayah), Anak-anak dengan orangtua yang menstimulasi anak untuk mengekspresikan perasaannya secara masalah secara lebih efektif dan memiliki keterampilan sosial yang lebih baik. Sedangkan menurut Fabes et al (dalam Rifa Hidayah) orang tua yang cenderung menghukum, tidak setuju konstuktif dan membantu mereka fokus pada pemecahan masalah akan cenderung mampu menghadapi dan menunjukkan emosi negatif, maka anak akan semakin menunjukkan emosi negatif dan kurang dapat melakukan penyesuaian sosial dengan baik (Iriani Indri Hapsari, 2016:293)

Pertemanan di sekolah bisa memberikan dampak positif maupun 
negatif. Dampak positifnya, anak bisa belajar bagaimana hidup bersama di masyarakat, bagaimana menyeuaikan diri di masyarakat dan berperilaku secara tepat. Sednagkan dampak negatif yang ditimbulkan dari teman sebaya diantaranya mencuri, menggunakan obat terlarang, minumminum keras, penyimpangan perilaku seksual da bertingkah antidosial. Selain itu bersikap prasangka terhadap kelompok lain, melakukan bullying baik terhadap teman sebaya ataupun adik kelasnya (Indriani Indri Hapsari, 2016:308)

Berdasarkan perkembangan emosional, selama masa usia sekolah, anak-anak tidak terlepas dari berbagai masalah yang muncul di rumah, di sekolah, saat bermain maupun di lingkungan. Keluarga menjadi tempat untuk berkeluh kesah saat anak memiliki masalah dengan teman atau sekolahnya, keluarga tempat untuk berdiskusi dan meminta pertimbangan untuk kegiatan yang akan dipilih anak, keluarga tempat terpenuhinya rasa aman dan nyaman serta kasih sayang yang dibutuhkan anak.

Namun, tidak semua anak memiliki keluarga seperti harapannya yaitu keluarga yang utuh dan memberinya kebutuhan afektif yang dibutuhkan anak. Banyak persoalan keluarga yang muncul dan merugikan anak dalam masa pertumbuhannya, contoh anak yang orang tuanya bercerai, anak yaim piatu, anak yang tinggal bersama orang tua tiri, anak yang hidup dalam kemiskinan, anak yang tinggal dengan orang tua yang kasar, anak yang tinggal dengan keluarga dalam kondisi broken home dan masalah keluarga lainnya.

Dalam hal ini ada beberapa pandangan dari filosofis tentang teori perkembangan, fungsi dan arah dari emosional itu sendiri yang mana peneliti uraikan dibawah ini sebagai berikut:

a. Studi Genetis. Menurut psikologis tradisional, emosi aspek dari insting pokok, misalnya pemeliharaan diri. Perubahanperubahan dalam tingkah laku emosional pada usia tertentu, karenanya merupakan hasil dari struktur organisme dan bukan dari pengalaman-pengalaman lingkungan.

b. Jhon B. Watson mempercayai bahwa emosi-emosi terdiri dari tiga pola pembawaan utama, yaitu rasa takut, rasa marah, dan kasih sayang. Tiga emosi ini memberikan respon-respon terhadap stimulus bahwa ini bukan tingkah laku bawaan, melainkan tingkah laku yang dapat diubah.

c. Katherine $\mathrm{Km}$ Bridges; telah menyajikan salah satu dari teoriteori emosi yang genetis. Ia menyatakan bahwa emosi dapat dilihat sebagai "Learned Pattern" 
daripada respon dan timbul dari suasana kabur pada kegembiraan yang umm, sebagai yang diinterprestasi oleh seorang pengamat (Baharuddin, Jogjakarta: 56).

Seorang anak hidup paling aktif didalam masa perkembangannya. Kepribadian sedang dalam pembentukkan dan di dalam stadium perkembangan banyak sekali terjadi perubahan atau modifikasi tingkah laku. Oleh karena itu, kita perlu mengetahui ciri tingkah laku normal pada setiap stadium perkembangan anak dan membedakan setiap tingkah laku anak dalam sosial emosional nya di lingkungan (Ema Aprianti, 2017:198).

Tidak setiap anak berhasil melewati perkembangan sosial emosional pada usia dini, sehingga kendala dapat saja terjadi. Sebagai pendidik sepatutnyalah untuk memahami perkembangan sosial emosional anak sebagai bekal dalam memberikan bimbingan terhadap anak agar mereka dapat mengembangkan kemampuan sosial dan emosinya dengan baik. Perlu kita kerahui bahwa proses pembelajaran sosial emosional pada anak selalu mendengarkan dan melakukan nasihat guru, juga dengan mengamati dan meniru hal-hal yang dilihatnya pada diri guru (NurjanahJurnal:51)
Salah satu aspek perkembangan pada diri anak yang perlu melibatkan bimbingan orang tua adalah pengembangan perilaku sosialemosional. Sebagian besar orang tua menyadari adanya hubungan erat antara perilaku sosial-emosional anak dengan keberhasilan dan kebahagiaan pada masa kanak-kanak dan masa kehidupan selanjutnya. Untuk menjamin bahwa anak dapat melakukan penyesuaian dengan baik, orang tua memberikan kesempatan kepada anak untuk menjalin kontak sosial dengan baik, orang tua memberikan kesempatan kepada anak untk menjalin kontak sosial-emosional dengan anak yang lain, dan berusaha memotivasi anak agar aktif secara sosial (Jaja Sutaja Jurnal, 2017:3).

Kemampuan untuk berinteraksi secara emosional sudah ada pada anak. Gejala perilaku emosional dapat diberikan dengan stimulus yang kuat. Proses perkembangan dan belajar anak dalam saling berinteraksi terkait satu sama lainnya dalam perkembangan anak tersebut. Proses pematangan emosi anak berjalan secara bertahap dalam perkembangannya (Sumiyati Jurnal, 2016: 85).

Dari hal ini peneliti dapat memberikan sedikit kesimpulan bahwasannya perkembangan sosial dan emosi anak memiliki peranan penting dalam hidup seseorang. Tiap bentuk emosi pada dasarnya membuat 
hidup terasa lebih menyenangkan. karena emosi dan hubungan sosial anak akan merasakan suatu getarangetaran perasaan dalam dirinya maupun orang lain. Hari-hari dan bulan-bulan dalam lingkungannya merupakan masa perkembangan dari sosial emosional anak itu sendiri.

\section{Permasalahan Ketidaktercapaian Sosial Emosional Pada Usia Sekolah}

Selama masa usia sekolah, anak-anak tidak terlepas dari berbagai masalah yang muncul di rumah, di sekolah, saat bermain maupun di lingkungan. Permasalah dapat muncul dalam hal akademik seperti malas belajar, suka mencontek, tidak mengerjakan tugas atau PR, tidak konsentrasi saat belajar, fobia sekolah dan maupun permasalahan dalam hal fisik, sosial dan emosi seperti suka mengganggu teman, bersk di kelas, sakit karena sering jajan sembarangan, bertengkar, bersikap agresif, gangguan eosi, perasaan cemas, stres serta depresi (Iriani Indri Hapsari, 2016:310).

Di bawah ini peneliti menuliskan bagian tentang beberapa permasalahan sosial emosional yang terjadi dilingkungan sekolah diantaranya sebagai berikut.

a. Agresi

Anak uisa sekolah bisa bersikap agresif dipengaruhi oleh beberapa hal diantaranya contoh nyata yang ia lihat sehari-hari dari sikap guru dan orang tua atau keluarganya yang bersikap agresi, media televisi yang banyak mepertontonkan aksi kekerasan, internet yang semakin mudah diakses membuat anak mudah membuka situs-situs kekerasan, rental video game kekerasan yang semakin banyak.

Salah satu agresi yang banyak bermunculan di sekolah adalah pola intimidasi yang dilakukan oleh anak laki-laki maupun anak perempuan. Anak laki-laki lebih banyak melakukan intimidasi dalam bentuk kekerasan pada anak perempuan maupun anak laki-laki. sedangkan anak perempuan lebih banyak melakukan kekerasan verbal dan fisik dan sasarannya adlah anak perempuan.

Dapat penulis simpulkan bahwa pada keadaan agresi sang anak dalam pendidikan sekolah melakukan berbagai interaksi bersama orang yang ada disekitarnya, seorang anak perlu perhatian dari guru dan orang tuanya agar ia dapat mengontrol sosial emosional sehingga tidak terjadinya hal-hal yang tidak baik seperti bentuk kekerasan dan lainnya.

b. Fobia Sekolah

Fobia sekolah pada awal masuk sekolah sering terkait dengan adanya separation anxiety disorder yaitu perasaan takut dan cemas berlebihan karena berpisah dengan rumah dan dari orang-orang terdekatnya seperti 
orang tua. Biasanya berlangsung dalam waktu tertentu sampai ia bisa menyesuaikan dirinya di sekolah (Iriani Indri Hapsari, 2016:311).

Selain itu, ada fobia sosial yaitu anak merasa takut dan cenderung menghindari situasi sosial. Anak merasa takut saat bicara di depan kelas sampai ia berkeringat, jantungnya berdebar-debar dan wajahnya kemerahan karena stres.

Dari fobia ini sendiri peneliti dapat mengatakan bahwasannya seorang anak ketika mendapatkan rasa fobia semasa sekolah maka akan membuat ia selalu merasa dalam ketakutan untuk berinterakasi maka peran guru tentu perlu dalam hal ini bisa dengan pendekatan maupun dengan memberi perhatian sehingga rasa fobia anak dapat teratasi.

\section{c. Oppositional Defiant Disorder}

ODD merupakan gangguan perilaku menantang yang ditandai dengan sikap negatifitas, sikap bermusuhan dan penantangan, serta ketidakpatuhan terhadap figur otoritatif dewasa. Perilaku yang sering terjadi pada anak ODD yaitu bertengkar, merampas, dan menyalahkan orang lain (Iriani Indri Hapsari, 2016: 312).

Berkenaan dengan hal ini peneliti dapat mengatakan bahwa dikala anak mengalami suatu gangguan dalam perilakunya maka akan berdampak ketika ia bersosial dengan teman, guru maupun orang tua, disini dapat dikatakan bahwasannya hal-hal yang dilihat dari baik berkenaan dengan perilaku orang dewasa maupun seumurannya akan menjadi contoh untuk ia melakukan kegiatan-kegiatannya.

d. Depresi

Depresi merupakan gangguan perasaan yang ditandai dengan simtom-simtom tertentu seperti merasa tidak berguna, merasa tidak memiliki teman, merasa tidak gembira, sulit konsentrasi, dan gelisah. Depres dapat diakibatkan karena tidak adanya kasih sayang dan perhatian dari orang tua maupun orang di sekitarnya, merasa gagal terus saat menginginkan sesuatu, tidak diterima oleh temannya, atau karena kehilangan orang yang dicintainya seperti saudara kandung ataupun orang tuanya (Iriani Indri Hapsari, 2016:313).

Berbicara mengenai keaadaan depresi peneliti dapat mengatakan bahwa dalam suasana sekolah tentu seorang atau bahkan banyak anak yang akan mengalami rasa kebosanan, bisa jadi hal itu dikarenakan gangguan perasaan yang tidak baik dikarenakan ketika ia melakukan interaksi dengan orang sekitarnya tidak dapat diterima dengan baik maka psikologi anak tersebut akan menjadi terganggu. Maka dari itu perena guru dan orang tua harus selalu menguatkan dan 
selalu memberikan perhatian, serta mengajarkan bagaiman bersosial dengan baik sehingga depresi pada anak akan teranlisir dan tidak dialaminya kembali.

\section{Edukasi Mengatasi Sosial Emosional Tidak Tercapai}

Proses pembelajaran bertujuan untuk mengambangkan kemampuan anak untuk mewujudkan proses pembelajaran yang lebih baik. Berbicara edukasi sendiri bertujuan untuk mengembangkan kepribadian baik dalam besosial mapun dalam mengembangakan emosional serta kecerdasan untuk bisa mengendalikan diri dan memiliki keterampilan (Ida Zusnani, 2013:188).

Dalam hal ini peneliti akan memberikan beberapa edukasi dalam mengatasi keadaan sosial emosional tidak tercapai diantaranya sebagai berikut:

a. Sistem Penghargaan

Buatlah sistem penghargaan kelas yang dapat diterima dan dapat diakses. Siswa berkesulitan belajar perlu memahami sistem penghargaan ini dikelas dan merasa ikut serta didalamnya. Janagan sampai siswa yang berkesulitan belajar meras "outlaws", mereka yang tidak memiliki kesepatan untuk mendapatkan penghargaan yang diterima siswa lain. Untuk memahami bagaimana mereka bisa mendapatkan penghargaan yang baik, para siswa perlu diberi pemahaman tetang bagaimana cara mendapatkan keuntungan sosial dari sikap positif dan hubungan sosial yang baik dikelas, beberapa siswa mungkin ingin pembuktian langsung di kelas.

b. Pengetahuan Sikap Berinteraksi Beberapa siswa yang berkualitas dalam belajar namun tidak memiliki kesadaran yang jelas pada sikapnya sendiri, serta dampaknya pada orang lain. Membantu siswa yang mengalami hal ini menjadi lebih mengenal akan sikap mereka dan dampaknya pada orang lain merupakan kesempatan yang berarti bagi perkembangan sosial dan emosional. Berbicara terbuka dan penuh perhatian kepada siswa ini mengenai sikapnya juga dapat menjadi langkah berinteraksi yang penting dalam membentuk hubungan yang saling percaya di antara mereka (Ida Zusnani, 2013:189).

\section{c. Mengajarkan Besikap Positif}

Ketika siswa berkesulitan dalam belajar maka ia akan menjadi lebih sadar terhadap sikapnya dan mendapat pemahaman yang lebih baik atas interaksi dengan orang lain, mereka akan merespon dengan baik intruksi-intruksi tentang cara membentuk hubungan yang baik dan sense of self (citra diri) yang lebih positif. Hal ini bisa ia lihat dari cara guru dan orang tua yang memberkan 
perhatian kepada dirinya (Ida Zusnani, 2016:190).

\section{SIMPULAN}

Berdasarkan hasil analisis observasi wawancara di SDN Jaranan bahwasannya perkembangan sosial emosional ada beberapa peserta didik yang mengalami broken home yang disebabkan oleh beberapa faktor. Disini peran guru sangat di butuhkan untuk mengatasi beberapa masalah yang dihadapi peserta didiknya. Untuk mengatasi masalah yang dihadapi peserta didiknya guru dapat mengambil langkah seperti memanggil orang tua untuk mengetahui faktor penyebab dari jiwa sosial peserta didik, pengarahan terhadap orang tua, dan pendekatan pada anak yang mengalami masalah sosial dan emosionalnya.

Teori perkembangan peneliti membagi dalam tiga teori yang terdiri dari teori perkembangan nativisme, teori empirisme, dan teori perkembangan konvergensi. Sedangkan psikologi perkembangan adalah studi psikologi yang mempelajari perkembangan manusia dan faktor-faktor yang membentuk perilaku seseorang sejak lahir sapai lanjut usia.

Berdasarkan perkembangan sosial, kebutuhan sosial anak makin kompleks, dan hubungan sosialnya makin luas, anak perlu memahami orang dewasa selain orang tua terasuk guru. Anak sudah memerlukan teman sebaya, terlihat pada usia 2 dan 3 tahun anak menunjukkan minat yang nyata terhadap anak-anak lain, karena perlu diupayakan terealisasinya pendidikan anak usia dini.

Berdasarkan perkembangan emosional, selama masa usia sekolah, anak-anak tidak terlepas dari berbagai masalah yang muncul diruma, di sekolah, saat bermain maupun di lingkungan. Keluarga jadi tempat untuk beekeluh kesah saat anak memiliki masalah dengan teman atau sekolahnya.

\section{DAFTAR PUSTAKA}

Ali Nugraha dan Yeni Rachmawati. 2006. Metode Pengembangan Sosial Emosional. Jakarta: Universitas Tebuka.

Baharuddin. 2016. Pendidikan Psikologi Perkembangan. Jogjakarta: Ar-Ruz Media.

David G, Myers. 2012. Psikologi Sosial. Jakarta: Salemba Humanika.

Iriani Indri Hapsari. 2016. Psikologi Perkembangan. Jakarta: Pramata Puri Media.

Purwa Atmaja Prawira. 2013. Psikologi Pendidikan dalam Perspektif Baru. Jogjakarta: Ar-Ruzz Media. 
Rifa Hidayah. 2009. Psikologi Pengasuhan Anak. Malang: UIN-MALANG Press.

Suyadi. 2010. Psikologi Belajar PAUD.

Yogyakarta:

Bintang

Pustaka Abadi.

Suharsi Arikunto. 2000. Manajemen

Penelitian. Jakarta: Rineka

Cipta.

Winda Gunarti. 2010. Metode

Pengembangan Perilaku dan

Kemampuan Dasar Anak Usia

Dini. Jakarta: Universitas Terbuka.

Yudrik Jahja. 2012. Psikologi

Perkembangan. Jakarta:

Kencana.

Yudrik Jahja. 2011. Psikologi

Perkembangan. Jakarta:

Prenada Media Group.

Nur Shintiya, Ni Made Sulastri, Luh

Ayu Tirtayani. 2015.

Penerapan Metode Outbound

Untuk Meningkatkan

Keterampilan Sosial Emosional

Anak. e-Journal PG PAUD

Universitar Pendidikan

Ganesha Jurusan

Pendidikan Guru Anak

Usia Dini (Volume 3 No.1-

Tahun 2015).

Ema Aprianti. 2017. Penerapan

Pembelajaran BCM Dalam

Konteks Perkembangan Sosial
Emosional Anak Usia Dini Di

Kober Baiturrahim Kabupaten

Bandung Barat (Vol.3 No.2

Oktober 2017).

Nurjannah. 2017. Jurnal Bimbingan Konseling dan Dakwah Islam (Vol.14. No.1 Juni 2017).

Jaja Sutaja. 2017. Jurnal Pendidikan Anak

Dampak Pola Asuh Orang Tua Terhadap Perkembangan Sosial-Emosional Anak (Vol.3 No.1. Febuari. 2017).

Umi Kulsum, Sri Witurachmi, Binti Muchrini. 2017. Jurnal Pengaruh Konsep Diri dan Dukungan Sosial Keluarga terhadap Kemampuan Karir Mahasiswa (Jurnal Tata Usaha UNS, Vo. 3 No.2. Agustus 2017).

Ani Wijrahayu, Dian Kristiani, Istiqlahiyah. 2018. Jurnal Kelekatan Ibu-Anak, Pertumbuhan Anak, dan Perkembangan Sosial Emosi Anak di Usia Sekolah (Jur. Tim. Kel September 2018. p Vol. 9 No. 3).

Sumiyati. 2016. Jurnal Mengembangkan Kemampuan Sosial Emosional Anak Usia Dini Melalui Pendidikan Dalam Keluarga (Jurnal Pendidikan RA, Vol. 1 No. 1 Tahun 2016). 